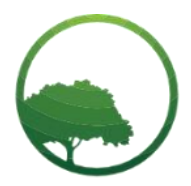

Research in Business \& Social Science

IJRBS VOL 10 NO 8 ISSN: 2147-4478

\title{
Optimal portfolio analysis of manufacturing entities in the Indonesia Sharia Stock Index
}

\author{
(D) Yunan Najamuddin (a) (iD Neni Meidawati (b) (iD) Nahar Savira Putri (c) (iD) Yuni Nustini ${ }^{(d)}$ \\ Duamar Nur Kholid ${ }^{(e) *}$ \\ ${ }^{(a, b, c, d, e)}$ Department of Accounting, Faculty of Business and Economics, Universitas Islam Indonesia, Yogyakarta, Indonesia
}

\begin{tabular}{l} 
A R T I C L E I N F O \\
\hline Article history: \\
Received 22 November 2021 \\
Received in rev. form 18 Dec. 2021 \\
Accepted 23 December 2021 \\
Keywords: \\
Risk, Return, Optimal Portfolio, \\
Indonesian Sharia Stock Index. \\
JEL Classification: \\
M10, G11
\end{tabular}

\begin{abstract}
A B S T R A C T
The purpose of this research is to determine the optimal portfolio for manufacturing entities listed on the Indonesian Sharia Stock Index based on a single index model test. The population of this research is manufacturing entities that have been listed in the Indonesian Sharia Stock Index on the Indonesia Stock Exchange for the Period 2019-2020. This study uses a purposive sampling technique using several criteria. Based on this technique, 31 entities meet the criteria. The results showed that the expected return was $5.65 \%$, and the possible risk was $0.22 \%$ for 15 (fifteen) stocks included in the optimal portfolio category.
\end{abstract}

(C) 2021 by the authors. Licensee SSBFNET, Istanbul, Turkey. This article is an open access article distributed under the terms and conditions of the Creative Commons Attribution (CC BY) license (http://creativecommons.org/licenses/by/4.0/).

\section{Introduction}

Investment is growing because of the support from public awareness in investing as the needs for future anticipation and the ease of service for growing investments. Tumewu (2019) stated that the desire of Indonesians to invest is relatively low compared to people in other countries. However, Indonesia has experienced a relatively better investment development viewed from the increasing public awareness to invest from various backgrounds and ages. Movanita (2019) reported 1.9 million investors in the capital market as of May. It proves that public interest in delaying consumption and utilizing their funds for investment in the capital market is relatively high compared to the previous year.

Investors have difficulty in making decisions to invest funds in the stock market. Investments can be conducted in shares that have sharia-compliant concessions listed on the Indonesian Sharia Stock Index, which Entity's activities are in line with sharia principles. The index is a performance indicator of the Islamic stock market in Indonesia (Bursa Efek Indonesia, 2020a). Stock buyers favor Islamic stocks in the industrial sector. Manufacturing entities can continue to maintain the development trend better because it is considered promising compared to other entities (Sholihah et al., 2017). For example, a business entity that produces consumer goods continues to grow because it produces products that are always in demand by consumers, especially women. Investors expect return from the invested funds. However, possible risks always arise from the invested funds. To minimize the risk and uncertainty of returns, investors must use accurate methods in making investment decisions by conducting investment analysis. All investors experienced unsystematic and systematic risk (Mulyati \& Murni, 2018). To obtain an optimal portfolio, stock selection can be analyzed using the Markowitz model or a single index based on the level of investor desire to get the expected return and the risk that will be borne by each portfolio choice (Tandelilin, 2001). Optimal portfolio selection by utilizing a single index model is

\footnotetext{
* Corresponding author. ORCID ID: 0000-0001-9036-8869

(c) 2021 by the authors. Hosting by SSBFNET. Peer review under responsibility of Center for Strategic Studies in Business and Finance.

https://doi.org/10.20525/ijrbs.v10i8.1506
} 
implemented by observing the market price of a stock that does not remain in line with market indices when the demand for shares increases or moves up, then the stock price in the market will rise (Sari \& Santoso, 2018). Investors analyze the stock portfolios according to their preferences to determine the selected stocks to receive optimal returns with a low level of risk and determine the amount of investment in each security using a single index model. Firdaus et al. (2018) stated that the more samples and the longer the research period, the more accurate the results when using a single index model because the analysis and calculation process is much simpler. Research related to determining the optimal portfolio already exists, as in previous research by Putri \& Wahyuni (2017), Sari \& Santoso (2018), Firdaus et al., (2018) and Pratama (2019). This research aims to conduct an optimal portfolio analysis of the manufacturing entities' shares contained in the Indonesia Sharia Stock index for 2019-2020 with a single index model.

\section{Literature Review}

\section{Theoretical and Conceptual Background}

Investment is an agreement on a number of funds, investment objects or resources hoping to receive some returns in the future (Tandelilin, 2001). Someone who invests his money in several stocks expects to get the expected return in the future from his investment (Halim, 2018). Suroto (2015) states that investors are risk-averse parties, which tend to avoid risk but expect maximum returns. Investors can invest their capital in the form of tangible assets or financial assets. Tangible assets are a form of investment such as buildings, vehicles, gold and others. Meanwhile, financial assets are investments in the form of claims documents indirectly from their holders to parties that issue securities such as deposits, shares and bonds. Investment contains risk, and investors do not know for sure the return that will be obtained. The relationship between return and risk is linear, the higher the return, the higher the risk. There are two types of returns: realized returns and expected returns (Hartono, 2010). The gap between the real return that can be obtained and the return that is expected to be obtained is a risk. The less the gap, the less the investment risk. According to Mulyati \& Murni (2018), risks can be categorized into 2: unsystematic and systematic risk. Risk-takers, risk-neutral, and risk-averse are risks accepted by investors (Halim, 2018). Risk takers are investors who bravely take the risk. It means that the investors dare to take higher risks when faced with choices at the same rate of return. Meanwhile, risk-neutral is investors' attitude in carefully making decisions, tends to be neutral to the risks they face, and tends to have the same demand for an increase in the rate of return for each increase in risk. In addition, risk-averse is the investors' attitude who refuse or do not dare to take risks and when faced with two choices, they will choose the slightest risk. This difference in preferences owned by investors in viewing a portfolio causes various types of investors' willingness to take risks. A capital market is a trading place for various instruments that does not last more than one year. Moreover, it is a place for trading activities and others where investors and issuers meet (Darmadji \& Fakhruddin, 2012). Fund voters are investors, while issuers are business entities that require capital and trade securities. A capital market is a meeting place for investors and issuers who conduct economic functions. For the state, the capital market function is to move the economy for the public to invest their money, and for issuers, it is a market to seek additional capital (Darmadji \& Fakhruddin, 2012; Samsul, 2015).

The indicator that shows each movement of various stock prices is called the stock market index. The Indonesia Sharia Stock Index (ISSI) is one of Indonesia's existing and recognized stock market indexes. Based on the Bursa Efek Indonesia (2020b), Otoritas Jasa Keuangan (OJK) sets criteria in the selection of sharia shares: the issuer does not conduct business in gambling, trading that is contrary to sharia, services that contain elements of usury, trading activities that have elements of gharar or maisir, conducting buying and selling goods or services that are unlawful in substance, and taking bribes. Some ratios that must be met are the ratio of total debt with interest and total assets of less than $45 \%$ and total income from interest and other income that does not meet the halal element compared to the total income and other income of less than $10 \%$. Whether controlled by individuals or entities, several investment assets in the form of shares are referred to as stock portfolios. Investors can make choices by diversifying their investment into more than one type of stock: a stock portfolio to reduce risk and increase the return obtained. Halim (2018) states that investors can allocate their funds to various investment alternatives by forming a portfolio to reduce negative correlated investment risk. An efficient portfolio is a portfolio that meets two criteria. First, the efficient set/efficient frontier provides the highest rate of return at a certain level of risk. Investors desire to achieve the maximum level of expected return by obtaining certain possible risks that they are willing to bear or finding alternative portfolios that offer a risk that is not high at a specific rate of return. Second, an optimal portfolio is the best portfolio selected and determined as an option by investors from various types contained in an efficient portfolio. Therefore, all optimal portfolios are quite efficient portfolios, but not all efficient portfolios are optimal portfolios (Rahmasita et al., 2014). Investors will choose a portfolio that matches their desire for return or risk that is bearable.

There are various models of methods or techniques in making investment decisions. In 1952, Harry Markowitz marked the beginning of modern portfolio theory. The model is concerned with creating an optimal asset portfolio by risk-averse investors. The Markowitz model states that investors should choose an efficient portfolio to avoid risk. The theory of the Markowitz model has several weaknesses, including being highly dependent on the results of statistical analysis, for example, risk calculations, prediction of expected results and others. These calculations require relatively a lot of information. In addition, Markowitz assumes that all securities carry risk. However, some securities have no risk (Sunariyah, 2007). The theory developed, and its simplification resulted in the application of the finance theory. The simplification is the input used and how to estimate the input used for analysis (Husnan, 2015). 
In 1963, William F. Sharpe developed the single-index model to simplify the Markowitz model. The single index model can simplify the calculations of the Markowitz model, which is quite complicated and complex by reducing the number of variables that need to be estimated and minimizing the input for portfolio theory analysis (Rahmasita et al., 2014). According to Tandelilin (2001), the Markowitz model's covariance is calculated using the variance-covariance relationship matrix, which requires complex relationships, specifically if the number of securities (n) is significant. Meanwhile, the risk is simplified in the single-index model by dividing it into two components: Entity uniqueness risk and market risk. In the Markowitz model, investors have limited choices of a portfolio consisting of risky assets. However, in practice, investors can freely determine portfolios with risk-free assets (Tandelilin, 2001). Risk-free assets are assets with a real rate of return in the future that can be ascertained at this time, while risky assets are assets with a real rate of return in the future that still has an element of uncertainty. In the single index model the joint movement of stock returns is assumed to be caused by the movement of the broad market index returns. The stock price in the market will increase if the demand for shares rises (Sari \& Santoso, 2018). On the other hand, if the demand for shares in the market declines, the stock price will depreciate. Therefore, there is a relationship between the returns from securities with a typical response to various types of changes in market value (Hartono, 2010). The portfolio formed through the single index model can be analyzed by comparing between the excess return to beta (ERB) value of each stock and the cut off rate (Ci) of each stock. ERB is the excess level of the risk-free rate of return on another asset. In contrast, the ratio between the market return rate variance and the sensitivity level of individual stocks to the stock error variance is referred to as the cut off rate. Stocks with a higher ERB value than the cut off rate will be classified into the optimal portfolio, meanwhile if the ERB has a fewer value than the cut off rate, it will not be included in the optimal portfolio (Firdaus et al., 2018). Suroto (2015), Margana \& Artini (2017), Putri \& Wahyuni (2017), Sari \& Santoso (2018), Firdaus et al. (2018), and Pratama (2019) researched optimal portfolio formation by utilizing a single-index model. Investors use this model to invest funds in the capital market as a basis for selecting investment decisions in the capital market. Analysis of the portfolio composition process using this model obtains a higher level of portfolio return than the risk level. Risk-averse investors prefer diversification rather than investing entirely in individual stocks. It is used as the basis for investors deciding to form a stock portfolio. The optimal portfolio formation is a way to reduce risk.

\section{Research and Methodology}

\section{Sample Data}

The population in this study is the entire stock of manufacturing entities listed on the Indonesia Sharia Stock Index, which are listed on the Indonesia Stock Exchange from January 2019 to January 2020. This study uses the purposive sampling technique by setting the following criteria:

i. Manufacturing entities that are regularly and uninterruptedly listed on the Indonesia Stock Exchange during the Period January 2019 to January 2020.

ii. Manufacturing entities that are included in the constituent group of the Indonesia Sharia Stock Index in the Period January 2019 - January 2020.

iii. Manufacturing entities that are not passively traded on the Indonesia Stock Exchange during the Period January 2019 January 2020 with a minimum trading frequency of three hundred times within one year.

The data in this study were collected from non-primary data found in www.yahoofinance.com, www.idx.co.id, and www.bi.go.id.

\section{Data analysis method}

The single index model in this study is used to analyze the optimal portfolio formation data. The steps in the data analysis process in this study are respectively explained as follows:

i. Providing a description and explanation of stock price developments and obtaining stock data for manufacturing entities registered on the Indonesia Sharia Stock Index from January 2019 to January 2020 that is closing price data at the end of the month, JCI and SBI.

ii. Calculating market parameters including the return, variance, and standard deviation originating from the Indonesia Stock Exchange.

Market Return

Market Variance

$$
\begin{gathered}
R_{M}=\frac{\sum_{t=1}^{n} R_{M}}{n} \\
R_{M=\frac{I H S G_{t}-I H S G_{t-1}}{I H S G_{t-1}}}
\end{gathered}
$$

Standard Deviation

$$
\sigma_{M}^{2}=\frac{\sum_{t=1}^{n}\left(R_{M}-E R_{M}\right)^{2}}{n-1}
$$

$$
\sigma_{M}=\sqrt{\frac{\sum_{t=1}^{n}\left[R_{i}-E\left(R_{i}\right)\right]^{2}}{n-1}}
$$


Calculating stock parameters including rate of return, variance and stock standard deviation.

Stock Return

Stock Variance

$$
\begin{gathered}
E\left(R_{i}\right)=\frac{\sum_{t=1}^{n} R_{i}}{n} \\
R_{i}=\frac{P_{t}-P_{t-1}}{P_{t-1}}
\end{gathered}
$$

Standard Deviation

$$
\sigma_{i}^{2}=\frac{\sum_{t=1}^{n}\left[R_{i}-E\left(R_{i}\right)\right]^{2}}{n-1}
$$

$$
\sigma_{i}=\sqrt{\frac{\sum_{t=1}^{n}\left[R_{i}-E\left(R_{i}\right)\right]^{2}}{n-1}}
$$

Calculating the covariance between the stock and the market

Calculating stock's systematic risk

$$
\sigma_{i M}^{2}=\frac{\sum_{t=1}^{n}\left[\left(R_{i}-E\left(R_{i}\right)\right)\left(R_{M}-E\left(R_{M}\right)\right]\right.}{n-1}
$$

Calculating the unsystematic risk of a stock

$$
\beta_{i}=\frac{\sigma_{i M}}{\sigma_{M}^{2}}
$$

$$
e_{e i}^{2}=\sigma_{i}^{2}-\beta_{i}^{2} \cdot \sigma_{M}^{2}
$$

Performing Alpha (ai) calculations of shares

$$
a_{i}=E\left(R_{i}\right)-\beta_{i} \cdot E\left(R_{M}\right)
$$

Calculating excess return to beta (ERB)

$$
E R B_{i}=\frac{E\left(R_{i}\right)-R_{B R}}{\beta_{i}}
$$

Compiling and determining stock ratings based on positive ERB values which have the highest to the least values

Calculating the cut off rate $(\mathrm{Ci})$ of stocks that have a non-negative ERB

Where, if:

$$
C_{i}=\frac{\sigma_{M}^{2} \sum_{i=1}^{i} A_{i}}{1+\sigma_{M}^{2} \sum_{i=1}^{i} B_{i}}
$$

Choosing the optimal portfolio by following conditions:

$$
\begin{gathered}
A_{i}=\frac{\left[E\left(R_{i}\right)-R_{B R}\right] \beta_{i}}{\sigma_{e i}^{2}} \\
B_{i}=\frac{\beta_{i}^{2}}{\sigma_{e i}^{2}}
\end{gathered}
$$

$\mathrm{ERB} \geq C^{*}=$ shares entered into the optimal portfolio,

$\mathrm{ERB} \geq C^{*}=$ then the stock is not included in the optimal portfolio.

Determining the proportion of the funds from each stock that forms the optimal portfolio

where:

$$
W_{i}=\frac{X_{i}}{\sum_{j=1}^{k} X_{j}}
$$

Calculating portfolio return

$$
X_{i}=\frac{\beta_{i}}{\sigma_{e j}^{2}}\left(E R B_{i}-C^{*}\right)
$$

$$
E\left(R_{p}\right)=a_{p}+\beta_{p} E\left(R_{M}\right)
$$


Calculating variance or risk portfolio

$$
\begin{gathered}
\beta_{p}=\sum_{i=1}^{n} W_{i} \beta_{i} \\
a_{p}=\sum_{i=1}^{n} W_{i} a_{i} \\
\sigma_{p}^{2}=\beta_{p}^{2} . \sigma_{M}^{2}+\left(\sum_{i=1}^{n} W_{i} a_{e i}\right)^{2}
\end{gathered}
$$

The following is the meaning of the symbols written in the above formulas: $\mathrm{n}=$ Period; $E\left(R_{M}\right)=$ Expected Return Market; $R_{M}=$ Return Market $; \sigma_{M}^{2}=$ Variance Market $; \sigma_{M}=$ Deviation Standard Market $; \mathrm{E}\left(\mathrm{R}_{\mathrm{i}}\right)=$ Expected Return Stock $; \mathrm{R}_{\mathrm{i}}=$ Stock Return $; \sigma_{i}^{2}=$ Stock Variance; $\sigma_{i}=$ Stock Standard Deviation; $\sigma_{i M}^{2}=$ Stock Covariance Return with Return Market; $\beta_{i}=$ Systemic Risk; $e_{e i}^{2}=$ Unsystematic Risk; $\alpha_{i}=$ Independent Return; $\mathrm{ERB}=$ Excess return to beta; $\mathrm{R}_{\mathrm{BR}}=$ Risk Free Rate $; \mathrm{C}^{*}=$ Cut Of Point; $\mathrm{X}_{\mathrm{i}}=\mathrm{Stock}$ Scales; $\mathrm{W}_{\mathrm{i}}=$ Fund Proportion; $\mathrm{E}\left(\mathrm{R}_{\mathrm{p}}\right)=$ Expected Return Portfolio; $\sigma_{p}^{2}=$ Variance Portfolio.

\section{Analysis and Findings}

\section{Research Sample}

Based on observations, 117 manufacturing entities on the Indonesia Stock Exchange from January 2019 to January 2020 are the population of this study. 31 out of 117 Entities meet the sample criteria. This study uses a single-index model method to determine the optimal portfolio composition of the 31 sample Entity stocks. Table 1 presents a complete list of the 31 sampled entity stocks. The closing price of each Entity that meets the sample criteria is the data used to find stock returns. The data is obtained from a search

\begin{tabular}{|c|c|c|}
\hline No & Stock Code & Issuer Name (PT. Tbk) \\
\hline 1. & ARNA & Arwana Citramulia \\
\hline 2. & ASII & Astra International \\
\hline 3. & AUTO & Astra Otoparts \\
\hline 4. & BRPT & Barito Pacific \\
\hline 5. & CLEO & Sariguna Primatirta \\
\hline 6. & CPIN & Charoen Pokphand Indonesia \\
\hline 7. & FOOD & Sentra Food Indonesia \\
\hline 8. & HOKI & Buyung Poetra Sembada \\
\hline 9. & ICBP & Indofood CBP Sukses Makmur \\
\hline 10. & INAF & Indofarma (Persero) \\
\hline 11. & INDF & Indofood Sukses Makmur \\
\hline 12. & INTP & Indocement Tunggal Prakarsa \\
\hline 13. & JPFA & Japfa Comfeed Indonesia \\
\hline 14. & JSKY & Sky Energy Indonesia \\
\hline 15. & KAEF & Kimia Farma (Persero) \\
\hline 16. & KLBF & Kalbe Farma \\
\hline 17. & MAIN & Malindo Feedmill \\
\hline 18. & MLIA & Mulia Industrindo \\
\hline 19. & MYOR & Mayora Indah \\
\hline 20. & SIDO & Industri Jamu dan Farmasi Sido Muncul \\
\hline 21. & SMBR & Semen Baturaja (Persero) \\
\hline 22. & SMGR & Semen Indonesia (Persero) \\
\hline 23. & SMSM & Selamat Sempurna \\
\hline 24. & SWAT & Sriwahana Adityakarta \\
\hline 25. & TPIA & Chandra Asri Petrochemical \\
\hline 26. & ULTJ & Ultrajaya Milk Industry \& Trading Company \\
\hline 27. & UNVR & Unilever Indonesia \\
\hline 28. & VOKS & Voksel Electric \\
\hline 29. & WOOD & Integra Indocabinet \\
\hline 30. & WSBP & Waskita Beton Precast \\
\hline 31. & WTON & Wijaya Karya Beton \\
\hline
\end{tabular}
on the www.yahoofinance.com page.

Table 1: List of Manufacturing Entities used as Research Samples January 2019-January 2020 
The Composite Stock Price Index (IHSG) is used as a market measure in the optimal portfolio formation with a single index model. The study uses IHSG data for the Period January 2019 to January 2020 accessed through www.yahoofinance.com. Information on risk-free interest rates derived from Bank Indonesia interest rates is used to obtain a risk-free interest rate or risk-free rate on an optimal portfolio using a single index. The Bank Indonesia (BI) rate used in this study is the monthly Bank Indonesia rate. The BI rate for January 2019 to January 2020 is collected from the Bank Indonesia website (www.bi.go.id). The BI rate used is the Period January 2019 to January 2020.

\section{Data Analysis Results}

The researcher analyzes the data to find the optimal portfolio by utilizing a single-index model for the stock group of manufacturing entities listed on the Indonesia Sharia Stock Index on the Indonesia Stock Exchange. Determination of the optimal portfolio by utilizing a single-index model, is based on calculating and comparing the ERB value with the cut-off rate value. If the ERB has a higher value than the cut-off rate, the stock will be included in the optimal portfolio.

The first step calculates the expected return, the standard deviation of stock covariance, and variance. Based on data analysis, the most significant expected return is generated by SMBR stock of 0.18996. Meanwhile, the lowest expected return is generated by BRPT shares of -0.06311. Six entities have a negative expected return value: BRPT, CLEO, HOKI, ICBP, SIDO, TPIA, and ULTJ. Based on the calculations, the most considerable stock variance is generated by JSKY shares of 0.15252 . Meanwhile, the stock with the lowest variance was produced by ULTJ stock with a 0.00093 value. Therefore, investors who reason will choose stocks that have a positive expected return. Meanwhile, based on variance, investors who have rational thinking will choose stocks with the lowest risk. However, it depends on the level of risk each investor is willing to accept.

The second step calculates the expected return, standard deviation, and variance in the market, using JCI data. Table 2 presents the calculation results of market standard deviation, expected market return, and market variance.

Table 2: Expected Return, Variance, and standard deviation in Market

\begin{tabular}{ll}
\hline $\mathrm{E}(\mathrm{Rm})$ & 0,00835 \\
\hline Variance & 0,00086 \\
\hline Standard Deviation & 0,02927 \\
\hline
\end{tabular}

Table 2 shows that the expected market return has a value of 0.00835 , the market variance has a value of 0.00086 and finally the market standard deviation has a value of 0.02927 . The calculation results of the expected market return with a positive value prove that investors can receive returns from investments in the capital market.

The third step calculates the risk-free rate. Determination of the stock portfolio with a single index model, the BI rate is used to calculate the rate of return on risk-free assets (RBR), also known as the risk-free rate. BI rate data accessed through the official website of Bank Indonesia is www.bi.go.id. This study uses the risk-free monthly rate with a value of 0.00465 or $0.46 \%$.

The fourth step calculates beta, alpha, residual error variance, and excess return to beta. Beta is a systematic risk-a risk that cannot be avoided. Beta will show the relationship between the sensitivity of stock return movements to market return movements. Beta with a positive value indicates that if the market return increases, the stock returns will rise as well. Conversely, a negative beta indicates that if the market return decreases, the stock returns will decrease. As shown in table 3, four entities have negative beta: CPIN, ICBP, JPFA, and ULTJ, which are not included in the optimal portfolio because they potentially reduce profits or increase risk so that twenty-seven Entities are categorized into portfolio candidates with optimal value. Meanwhile, residual error variance is an unsystematic risk-a risk that might be avoided. This type of risk is only owned by an entity so that it can be eliminated by diversification.

ERB provides information on the relationship between return and risk, which is used as one of the determinants of investment. Determination of the optimal portfolio with a single-index model uses the ERB value and cut-off rate as a determinant of the optimal portfolio candidate. ERB itself is an excess of risk-free rate stock returns. The calculations show the most considerable ERB value is KAEF shares of 0.27961 , and the lowest ERB value is JPFA shares of -0.81032 . 
Table 3: Beta, Variance Error Residual, Alpha, and Excess return to beta (ERB)

\begin{tabular}{|c|c|c|c|c|c|}
\hline No & Stock Code & $\beta_{i}$ & $\alpha i$ & $e_{e i}^{2}$ & ERB \\
\hline 1. & ARNA & 0,17496 & 0,00817 & 0,00376 & 0,02851 \\
\hline 2. & ASII & 1,21867 & 0,01603 & 0,00359 & 0,01769 \\
\hline 3. & AUTO & 0,84014 & 0,01619 & 0,00124 & 0,02209 \\
\hline 4. & BRPT & 1,26793 & $-0,07370$ & 0,02061 & $-0,05344$ \\
\hline 5. & CLEO & 0,45710 & $-0,04324$ & 0,01076 & $-0,09640$ \\
\hline 6. & CPIN & $-0,31365$ & 0,01652 & 0,01091 & $-0,02949$ \\
\hline 7. & FOOD & 2,56847 & 0,08260 & 0,02624 & 0,03870 \\
\hline 8. & HOKI & 1,36306 & $-0,01993$ & 0,00902 & $-0,00968$ \\
\hline 9. & ICBP & $-0,09442$ & $-0,00234$ & 0,00297 & 0,08231 \\
\hline 10. & INAF & 1,59692 & 0,17362 & 0,06720 & 0,11416 \\
\hline 11. & INDF & 0,33318 & $-0,00170$ & 0,00400 & $-0,01071$ \\
\hline 12. & INTP & 1,36156 & 0,00488 & 0,00577 & 0,00852 \\
\hline 13. & JPFA & $-0,07216$ & 0,06372 & 0,01419 & $-0,81032$ \\
\hline 14. & JSKY & 2,48454 & 0,13934 & 0,14723 & 0,06256 \\
\hline 15. & KAEF & 0,38113 & 0,10803 & 0,04503 & 0,27961 \\
\hline 16. & KLBF & 1,51178 & $-0,00080$ & 0,00331 & 0,00474 \\
\hline 17. & MAIN & 1,90754 & 0,04810 & 0,01017 & 0,03113 \\
\hline 18. & MLIA & 1,63052 & 0,08799 & 0,04242 & 0,05947 \\
\hline 19. & MYOR & 0,46261 & 0,02171 & 0,00130 & 0,04524 \\
\hline 20. & SIDO & 0,51444 & $-0,03086$ & 0,00822 & $-0,06067$ \\
\hline 21. & SMBR & 7,21102 & 0,12975 & 0,04818 & 0,02570 \\
\hline 22. & SMGR & 1,68239 & $-0,00553$ & 0,00571 & 0,00230 \\
\hline 23. & SMSM & 0,65195 & 0,00651 & 0,01022 & 0,01121 \\
\hline 24. & SWAT & 1,28478 & 0,02243 & 0,00218 & 0,02219 \\
\hline 25. & TPIA & 1,93288 & $-0,03996$ & 0,01479 & $-0,01473$ \\
\hline 26. & ULTJ & $-0,16792$ & $-0,02697$ & 0,00091 & 0,19664 \\
\hline 27. & UNVR & 0,43564 & 0,01684 & 0,00234 & 0,03634 \\
\hline 28. & VOKS & 3,87315 & $-0,01456$ & 0,02650 & 0,00339 \\
\hline 29. & WOOD & 1,71205 & 0,01930 & 0,02789 & 0,01691 \\
\hline 30 & WSBP & 1,80820 & 0,02073 & 0,00355 & 0,01725 \\
\hline 31. & WTON & 2,33840 & $-0,00677$ & 0,01351 & 0,00347 \\
\hline
\end{tabular}

The sixth step determines the optimal stock portfolio with a single-index model by making a stock order based on the largest to the smallest ERB values. The aim is to identify which stocks have the most considerable ERB value quickly. Table 4 presents information on twenty-seven stocks that become candidates for the optimal portfolio in this study.

The fifth step calculates the cut-off rate (ci) and set the cut-off point $\left(\mathrm{c}^{*}\right)$. The cut-off rate is used in determining the portfolio with the optimal value with a single index model by comparing the ERB value with the cut-off rate. Meanwhile, the cut-off points or $\mathrm{C}^{*}$ is the highest cut-off rate or the maximum value of all share cut-off rates. The cut-off point is the limiting point for which stocks are included in the optimal portfolio. Table 4 presents a comparison of the ERB value with the cut off rate. The optimal portfolio is formed by comparing the ERB value with the cut-off rate. If the stock has an ERB value higher than the cut-off rate, the stock can be included in the optimal stock portfolio.

Vice versa, if the stock has an ERB value lower than the cut-off rate, the stock cannot be included in the optimal portfolio. After getting the optimal portfolio candidate by comparing the ERB value with the cut-off rate. Then the optimal portfolio candidate results are selected again, which is compared to the cut-off point as a barrier to which stocks are included as optimal portfolio candidates. The cut-off point of this study was collected from SMBR shares, which was 0.01235 . The determining results of the cut-off point can be seen in Table 4. 
Table 4: Cut Off Rate (Ci) dan Cut Off Point (C*)

\begin{tabular}{|c|c|c|c|}
\hline No. & Stock Code & ERB & $\mathbf{C i}$ \\
\hline 1. & KAEF & 0,27961 & 0,00077 \\
\hline 2. & INAF & 0,11416 & 0,00360 \\
\hline 3. & JSKY & 0,06256 & 0,00217 \\
\hline 4. & MLIA & 0,05947 & 0,00303 \\
\hline 5. & MYOR & 0,04524 & 0,00559 \\
\hline 6. & FOOD & 0,03870 & 0,00686 \\
\hline 7. & UNVR & 0,03634 & 0,00236 \\
\hline 8. & MAIN & 0,03113 & 0,00730 \\
\hline 9. & ARNA & 0,02851 & 0,00020 \\
\hline 10. & SMBR & 0,02570 & 0,01235 \\
\hline 11. & SWAT & 0,02219 & 0,00873 \\
\hline 12. & AUTO & 0,02209 & 0,00725 \\
\hline 13. & ASII & 0,01769 & 0,00463 \\
\hline 14. & WSBP & 0,01725 & 0,00761 \\
\hline 15. & WOOD & 0,01691 & 0,00140 \\
\hline 16. & SMSM & 0,01121 & 0,00039 \\
\hline 17. & INTP & 0,00852 & 0,00184 \\
\hline 18. & KLBF & 0,00474 & 0,00176 \\
\hline 19. & WTON & 0,00347 & 0,00089 \\
\hline 20. & VOKS & 0,00339 & 0,00111 \\
\hline 21. & SMGR & 0,00230 & 0,00069 \\
\hline 22. & HOKI & $-0,00968$ & $-0,00145$ \\
\hline 23. & INDF & $-0,01071$ & $-0,00025$ \\
\hline 24. & TPIA & $-0,01473$ & $-0,00262$ \\
\hline 25. & BRPT & $-0,05344$ & $-0,00335$ \\
\hline 26. & SIDO & $-0,06067$ & $-0,00163$ \\
\hline 27. & CLEO & $-0,09640$ & $-0,00158$ \\
\hline$C^{*}$ & & & 0,01235 \\
\hline
\end{tabular}

Table 4 shows that thirteen out of twenty-seven stocks that become candidates for the optimal portfolio cannot be categorized into the optimal portfolio because they have a smaller ERB value than the cut-off rate and cut-off point. The thirteen stocks are WSBP, SMSM, INTP, KLBF, WTON, VOKS, SMGR, HOKI, INDF, TPIA, BRPT, SIDO, and CLEO. Therefore, there are only fifteen stocks included in the optimal portfolio: ARNA, ASII, AUTO, FOOD, INAF, JSKY, KAEF, MAIN, MLIA, MYOR, SMBR, SWAT, UNVR, WOOD, and WSBP. The shares are categorized in the optimal portfolio category because the 15 stocks mentioned have lower ERB values than the cut-off rate. The seventh step calculates the proportion of funds invested in each share. Table 5 presents the calculation results of the weighted scale and the proportion of funds from each share.

Table 5: Proportion of Funds of Each Share

\begin{tabular}{|c|c|c|c|c|}
\hline No & Stock Code & $X_{i}$ & $W_{i}$ & Wi Percentage \\
\hline 1. & MYOR & 11,70148 & 0,23713 & $23,71 \%$ \\
\hline 2. & AUTO & 6,60737 & 0,13390 & $13,39 \%$ \\
\hline 3. & SWAT & 5,79645 & 0,11746 & $11,75 \%$ \\
\hline 4. & UNVR & 4,46005 & 0,09038 & $9,04 \%$ \\
\hline 5. & MAIN & 3,52192 & 0,07137 & $7,14 \%$ \\
\hline 6. & FOOD & 2,57938 & 0,05227 & $5,23 \%$ \\
\hline 7. & WSBP & 2,49649 & 0,05059 & $5,06 \%$ \\
\hline 8. & INAF & 2,41957 & 0,04903 & $4,90 \%$ \\
\hline 9. & KAEF & 2,26204 & 0,04584 & $4,58 \%$ \\
\hline 10. & SMBR & 1,99818 & 0,04049 & $4,05 \%$ \\
\hline 11. & ASII & 1,81318 & 0,03674 & $3,67 \%$ \\
\hline 12. & MLIA & 1,81133 & 0,03671 & $3,67 \%$ \\
\hline 13. & JSKY & 0,84739 & 0,01717 & $1,72 \%$ \\
\hline 14. & ARNA & 0,75143 & 0,01523 & $1,52 \%$ \\
\hline \multirow[t]{2}{*}{15.} & WOOD & 0,28014 & 0,00568 & $0,57 \%$ \\
\hline & & 49,27388 & 1 & $100 \%$ \\
\hline
\end{tabular}


The calculations show that the most significant proportion of funds generated by MYOR shares was 23.71\%, while the lowest proportion of funds generated by WOOD shares is $0.57 \%$. Based on the proportion of funds, rational investors will certainly prefer stocks with the most significant proportion of funds. The eighth step calculates the portfolio return or the expected return portfolio. Table 6 shows the calculation results of alpha portfolio, beta portfolio, and return portfolio returns. The return obtained from the formation of the optimal portfolio is 0.05647 or $5.65 \%$ from the calculations conducted. The portfolio rate of return was above the market rate of return of $0.84 \%$ and the average risk-free rate of $0.46 \%$. Thus, the portfolio rate of return is considered promising.

Table 6: Optimal Portfolio Return

\begin{tabular}{|c|c|c|c|}
\hline No. & Stock Code & 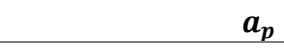 & $\boldsymbol{\beta}_{p}$ \\
\hline 1. & ARNA & 0,00012 & 0,00266 \\
\hline 2. & ASII & 0,00059 & 0,04478 \\
\hline 3. & AUTO & 0,00217 & 0,11249 \\
\hline 4. & FOOD & 0,00432 & 0,13426 \\
\hline 5. & INAF & 0,00851 & 0,07830 \\
\hline 6. & JSKY & 0,00239 & 0,04267 \\
\hline 7. & KAEF & 0,00495 & 0,01747 \\
\hline 8. & MAIN & 0,00343 & 0,13614 \\
\hline 9. & MLIA & 0,00323 & 0,05985 \\
\hline 10. & MYOR & 0,00515 & 0,10970 \\
\hline 11. & SMBR & 0,00525 & 0,29200 \\
\hline 12. & SWAT & 0,00263 & 0,15092 \\
\hline 13. & UNVR & 0,00152 & 0,03937 \\
\hline 14. & WOOD & 0,00011 & 0,00972 \\
\hline 15. & WSBP & 0,00105 & 0,09148 \\
\hline \multicolumn{2}{|c|}{ Total } & 0,04544 & 1,32180 \\
\hline \multicolumn{2}{|c|}{$\mathrm{E}\left(R_{M}\right)$} & 0,00835 & \\
\hline \multicolumn{2}{|c|}{$\mathrm{E}\left(R_{p}\right)=\left(a_{p}+\left(\beta_{p} . E\left(R_{M}\right)\right.\right.$} & & 0,05647 \\
\hline
\end{tabular}

The ninth step calculates the optimal portfolio risk. Table 7 shows the calculation results of portfolio risk.

Table 7: Optimal Portfolio Risk

\begin{tabular}{llll}
\hline No. & Stock Code & $\boldsymbol{\sigma e}_{\boldsymbol{p}}^{\mathbf{2}}$ & 0,00000 \\
\hline 1. & ARNA & 0,00000 \\
\hline 2. & ASII & 0,00002 \\
\hline 3. & AUTO & 0,00007 \\
\hline 4. & FOOD & 0,00016 \\
\hline 5. & INAF & 0,00004 \\
\hline 6. & JSKY & 0,00009 \\
\hline 7. & KAEF & 0,00005 \\
\hline 8. & MAIN & 0,00006 \\
\hline 9. & MLIA & 0,00007 \\
\hline 10. & MYOR & 0,00008 \\
\hline 11. & SMBR & 0,00003 \\
\hline 12. & SWAT & 0,00002 \\
\hline 13. & UNVR & 0,00000 \\
\hline 14. & WOOD & 0,00001 \\
\hline 15. & WSBP & 0,00072 \\
\hline Total & & 1,74717 \\
\hline \multicolumn{2}{l}{} & & 0,00086 \\
\hline Variance Portfolio & $\beta_{p}^{2}$ & 0,00222 \\
\hline Portfolio Standard Deviation & $\sigma_{m}^{2}$ & 0,04708
\end{tabular}

Portfolio Standard Deviation 
The calculations in table 7 show that the risk obtained from forming the optimal portfolio is 0.00222 , and the standard deviation is 0.04708. Overall, it can be observed that there are individual stocks that produce a rate of return that is not smaller than the portfolio rate of return. However, the risk that must be borne will not be less than the risk contained in the portfolio. Thus, it proves that forming an optimal portfolio or performing a diversification process can reduce the risks of investments.

\section{Discussion}

Investment is a commitment to an amount of money or funds, investment objects or other resources that are implemented at this time, hoping for receiving benefits in the future (Tandelilin, 2001). The decision to invest must consider the return and risk. Risk consists of systematic risk and unsystematic risk. One of the alternatives to avoid unsystematic risk is to perform a diversification process or diversification by forming an optimal stock portfolio. This study uses the single-index model method in determining the optimal portfolio. Determination of the optimal portfolio with a single index model is implemented by comparing the ERB value and the cutoff rate value of each stock. If the ERB value is less than the stock cut-off rate value, it will be included in the optimal portfolio. On the other hand, if the ERB value is less than the cut-off rate, the stock is not included in the optimal portfolio. An investor can use Beta, ERB and return values in considering investment decisions and optimizing portfolios. Reasonable investors are likely to prefer stocks that have a positive rate of return. Based on the calculation results of determining the optimal portfolio in thirty-one research samples, 15 stocks can be categorized into optimal portfolios with optimal returns.

Based on data analysis, fifteen Entities are included in the optimal portfolio, specifically ARNA, ASII, AUTO, FOOD, INAF, JSKY, KAEF, MAIN, MLIA, MYOR, SMBR, SWAT, UNVR, WOOD, and WSBP. With the formation of an optimal portfolio, this study's results will present more stock choices that can be used as a benchmark for alternative investments by both investors and potential investors.

In this research, fifteen stocks are included in the optimal portfolio. Furthermore, these fifteen shares are necessary to calculate the proportion of funds from each share. It aims to determine the large proportion of the selected stock funds that are reasonable for investment.

Based on the data analysis, Table 5 presents information on the proportion amount of funds that form the optimal stock portfolio. The proportion of funds that form an optimal stock portfolio is as follows: ARNA 1.52\%, ASII 3.67\%, AUTO 13.39\%, FOOD 5.23\%, INAF $4.90 \%$, JSKY $1.72 \%$, KAEF $4.58 \%$, MAIN by $7.14 \%$, MLIA by $3.67 \%$, MYOR by $23.71 \%$, SMBR by $4.05 \%$, SWAT by $11.75 \%$, UNVR by $90.04 \%, 0.57 \%$ WOOD, and $5.06 \%$ WSBP.

Table 8: List of Manufacturing Entities Included in Optimal Portfolio

\begin{tabular}{lll}
\hline No. & Stock Code & Note (PT., Tbk) \\
\hline 1. & ARNA & Arwana Citramulia \\
\hline 2. & ASII & Astra International \\
\hline 3. & AUTO & Astra Otoparts \\
\hline 4. & FOOD & Sentra Food Indonesia \\
\hline 5. & INAF & Indofarma (Persero) \\
\hline 6. & JSKY & Sky Energy Indonesia \\
\hline 7. & KAEF & Kimia Farma (Persero) \\
\hline 8. & MAIN & Malindo Feedmill \\
\hline 9. & MLIA & Mulia Industrindo \\
\hline 10. & MYOR & Mayora Indah \\
\hline 11. & SMBR & Semen Baturaja (Persero) \\
\hline 12. & SWAT & Sriwahana Adityakarta \\
\hline 13. & UNVR & Unilever Indonesia \\
\hline 14. & WOOD & Integra Indocabinet \\
\hline 15. & WSBP & Waskita Beton Precast \\
\hline
\end{tabular}

Based on the data analysis, fifteen stocks can be categorized into the optimal portfolio. The fifteen stocks yield the best returns and risk levels. The stock portfolio has a return of 0.05647 followed by a risk of 0.00222 . Table 8 presents manufacturing entities categorized as optimal portfolios.

\section{Conclusion}

Fifteen stocks have a composition following the formation of an optimal stock portfolio by utilizing a single index model. Fifteen stocks that fall into the optimal category include ARNA, ASII, AUTO, FOOD, INAF, JSKY, KAEF, AIN, MLIA, MYOR, SMBR, SWAT, UNVR, WOOD, and WSBP. Based on data analysis, it implies that investors will be able to invest by considering the fifteen optimal stock portfolios included in the shares of manufacturing entities listed on the Indonesia Sharia Stock Index, which are listed on the Indonesia Stock Exchange, because they are proven to reduce risk with a promising rate of return. 
All authors have read and agreed to the published version of the manuscript.

Author Contributions: Conceptualization, Y.N, N.M, N.S.P.; methodology, Y.N., N.M., Y.N.; validation, Y.N., N.M., M.N.K..; formal analysis, Y.N., N.M., N.S.P.; investigation, N.M., N.S.P., Y.N..; resources, N.S.P., N.M.; writing—original draft preparation, Y.N., N.M., N.S.P.; writingreview and editing, N.M., M.N.K.; supervision, Y.N., N.M.; project administration, N.S.P.; funding acquisition, N.M., N.S.P.

Funding: This research was funded by Accounting Development Center, Faculty of Business and Economics, Universitas Islam Indonesia, Yogyakarta.

Informed Consent Statement: Informed consent was obtained from all subjects involved in the study.

Data Availability Statement: The data presented in this study are available on request from the corresponding author. The data are not publicly available due to restrictions.

Conflicts of Interest: The authors declare no conflict of interest.

\section{References}

Bursa Efek Indonesia. (2020a). Indeks Saham Syariah. www.Idx.Co.Id. https://www.idx.co.id/idx-syariah/indeks-saham-syariah/ Bursa Efek Indonesia. (2020b). Produk Syariah. www.Idx.Co.Id. https://www.idx.co.id/idx-syariah/produk-syariah/

Darmadji, T., \& Fakhruddin, H. M. (2012). Pasar Modal Di Indonesia (Ketiga).Jakarta: Salemba Empat.

Firdaus, I., Anah, S., \& Nadira, F. (2018). Analisis Pembentukan Portofolio Optimal Menggunakan Model Indeks Tunggal. Jurnal Ekonomi, 23(2), 203-226. http://dx.doi.org/10.24912/je.v23i2.369

Halim, A (2018). Analisis Investasi dan Aplikasinya: Dalam Aset Keuangan dan Aset Riil (Kedua). Jakarta: Salemba Empat.

Husnan, S. (2015). Dasar-Dasar Teori Portfolio \& Analisis Sekuritas. Kelima, 1-439. Yogyakarta: STIM YKPN.

Hartono, J (2010). Teori Portofolio dan Analisis Investasi (Ketujuh). Yogyakarta: BPFE.

Margana, I. G. R. R., \& Artini, L. G. S. (2017). Pembentukan Portofolio Optimal Menggunakan Model Indeks Tunggal. E-Jurnal Manajemen, 6(2), 748-771.

Mulyati, S., \& Murni, A. (2018). Analisis Investasi dan Penentuan Portofolio Saham Optimal Dengan Metode Indeks Tunggal (Studi Empiris Pada IDX 30 Yang Terdaftar Di Bursa Efek Indonesia Periode Agustus 2017-Januari 2018). Jurnal Akuntansi Dan Keuangan, 6(2), 129-138. https://doi.org/10.29103/jak.v6i2.1831

Movanita, A, N, K. (2019). Per Mei 2019, Investor Pasar Modal Indonesia Mencapai 1,9 Juta. Kompas.Com. https://money.kompas.com/read/2019/06/26/141032126/per-mei-2019-investor-pasar-modal-indonesia-mencapai-19-juta

Pratama, L. A. (2019). Analisis Pembentukan Portfolio Saham Optimal Menggunakan Metode Single Index Model (Studi Empiris pada Saham Indeks LQ 45 di Bursa Efek Indonesia). Jurnal Ilmu Manajemen, 16(1), 48-60. https://doi.org/10.21831/jim.v16i1.25064

Putri, D. A. R., \& Wahyuni, D. U. (2017). Analisis Portfolio Optimal Dengan Model Indeks Tunggal Pada Perusahaan Manufaktur di BEI. Jurnal Ilmu Dan Riset Manajemen, 6(2), 1-21.

Rahmasita, F., Hidayat, R. R., \& Azizah, D. F. (2014). Pembentukan Poertofolio Optimal Dengan Menggunakan Single Index Model (Studi Pada Saham-Saham Sektor Industri Dasar dan Kimia Bursa Efek Indonesia Periode 2011-2013. Jurnal Administrasi Bisnis, 16(11), 1-10.

Samsul, D. M. (2015). Pasar Modal \& Manajemen Portofolio (A. Maulana (ed.); Kedua). Jakarta:Erlangga.

Sari, F. A., \& Santoso, B. H. (2018). Analisis Portofolio Optimal Dengan Model Indeks Pada Perusahaan Manufaktur Dalam Indeks LQ 45 di BEI. Jurnal Ilmu Dan Riset Manajemen, 5(5), 1-22.

Sholihah, I. M., Syaparuddin, \& Nurhayani. (2017). Analisis Investasi Sektor Industri Manufaktur, Pengaruhnya Terhadap Pertumbuhan Ekonomi dan Penyerapan Tenaga Kerja di Indonesia. Paradigma Ekonomika, 12, 11-24. https://doi.org/10.22437/paradigma.v12i1.3930

Sunariyah. (2007). Pengantar Pengetahuan Pasar Modal (Kelima). Yogyakarta: Sekolah Tinggi Ilmu Manajemen YKPN.

Suroto. (2015). Analisis Portfolio Optimal Dengan Model Indeks Tunggal (Studi Empiris Pada Saham LQ 45 di Bursa Efek Indonesia Periode Agustus 2012-Juli 2015). Media Ekonomi Dan Manajemen, 30(2), 1-17. http://dx.doi.org/10.24856/mem.v30i2.243

Tandelilin, E. (2001). Analisis Investasi dan Manajemen Portfolio (Pertama). Yogyakarta: BPFE.

Tumewu, F. J. (2019). Minat Investor Muda Untuk Berinvetasi Di Pasar Modal Melalui Teknologi Fintech. Ilmiah Manajemen Bisnis Dan Inovasi, 6, 133-146. https://doi.org/10.35794/jmbi.v6i2.26170

Publisher's Note: SSBFNET stays neutral with regard to jurisdictional claims in published maps and institutional affiliations.

\section{(C) (1)}

(C) 2021 by the authors. Licensee SSBFNET, Istanbul, Turkey. This article is an open access article distributed under the terms and conditions of the Creative Commons Attribution (CC BY) license (http://creativecommons.org/licenses/by/4.0/).

International Journal of Research in Business and Social Science (2147-4478) by SSBFNET is licensed under a Creative Commons Attribution 4.0 International License. 